\title{
Biological Control Agents of Mites
}

ISSN: 2637-7659

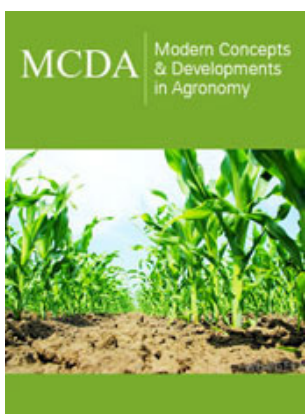

*Corresponding author: Ayșe Yeşilayer, Tokat Gaziosmanpaşa University, Agricultural Faculty, Plant Protection Department, Tokat, Turkey

Submission: 眥 February 18, 2021

Published: 此 March 25, 2021

Volume 8 - Issue 2

How to cite this article: Ayșe Yeşilayer. Biological Control Agents of Mites. Mod Concep Dev Agrono. 8(2). MCDA. 000685. 2021. DOI: 10.31031/MCDA.2021.08.000685

Copyright@ Ayșe Yeșilayer. This article is distributed under the terms of the Creative Commons Attribution 4.0 International License, which permits unrestricted use and redistribution provided that the original author and source are credited.

\section{Ayșe Yeşilayer*}

Tokat Gaziosmanpaşa University, Agricultural Faculty, Plant Protection Department, Tokat, Turkey

\section{Abstract}

One of the methods used to reduce their negative effects in pest control with synthetic pesticides is biological control. Phytoseiid mites are used as biological control agents for management of pest mites of agricultural and horticultural plants. These mites are efficient predators able to control plant parasitic mites and small arthropods. This review provides overview biological control and using predatory mites.

\section{Introduction}

Initially, during the centuries development of agriculture, the use of all kinds of technical and technological tools to meet the needs of people was very important. Therefore, the use of chemical pesticides in traditional agriculture has been used frequently and intensively during pest and disease management. These pesticides, which are used to control pests in industrial agriculture, have caused damage to humans and the environment over time. Up to now (presently thoruought out the globe) approximately more than two million tons of synthetic pesticides are used, of which $47.5 \%$ herbicides, $29.5 \%$ insecticides, $17.5 \%$ fungicides [1]. Pesticides use is estimated to reach 3.5 million tons, in 2020 [2]. Nowadays, applications that are precision to human and environmental health have started to attract increasing attention. The European Union states that the use of pesticides should be reduced by $50 \%$ until 2030 for the sustainability of Farm to Fork (F2F) and Biodiversity (BDS) [3].

Biological control applications, in which the control of pests and benefits included in the integrated control management (IPM), are used all over the world. Living organism live in harmony with each other in nature. Biological control includes predators, parasitoids and entomopathogens used in the control of pests such as insects, mites, fungi, viruses and weeds that cause damage in cultivated plants [4].

Biological control against insects and mites is part of Integrated Pest Management (IPM), in many parts of the world and it's very important to IPM [5]. There are many pests in the greenhouse and open field. One of the important groups is mites. Mites are smal arthropods, and most of them are tiny less than $1 \mathrm{~mm}$ lenght. They have been seen for the first time Rober Hook [6]. Plant parasitic mites are consisting of about 55.00 species and an estimate 1 million more species await discover [7]. Plant pest mites so called Spider mites (TetranchidaeAcari) are polyphagous herbivors. Phytoseiid mites play role control to phytophagus mites, esspecially eriophyid and tetranychid mites $[8,9]$. Two of the natural enemies used in the biological control of red spiders, Phytoseilus persimilis and Amblyseius californicus.

Phytoseilus persimilis is the natural enemy of the red spider and its origin is the Mediterranean, it reproduces faster than prey and they finds prey easily. It is produced commercially in Turkey and Europe [10]. Amblyseius californicus is also known as Neoseiulus californicus. Although the origin of this mite is in California and Florida, it is also common in the Mediterranean [11-13].

Both predator mites are applied against harmful red spider [14] in ornamental plants, agriculture and horticulture plants, very successfully. Phytoseiid mites that are able to reduce the population of spider mites. Biological control is not based on the production of beneficial and natural enemies, but on the protection of those present in nature. Lastly, in the control of pests, less use of chemicals will be increase the success of biological control in the future. In addition the biological control is sustainable and has no negative effects on the environment, it makes it more advantageous than other control methods. 


\section{References}

1. (2014) Worldwide pesticide use. In: De A, Bose R, Kumar A, Mozumdar $\mathrm{S}$ (Eds.), Targeted delivery of pesticides using biodegradable polymeric nanoparticles. Springer, Berlin, pp: 5-6.

2. Zhang W (2018) Global pesticide use: profle, trend, cost/beneft and more. Proc Int Acad Ecol Environ Sci 8(1): 1-27.

3. Anonymous (2020) Avrupa pestisitlere dayalı tarım sistemini değiștiriyor.

4. Brodeur J, Cory J, Harwood JD, Hoffmann JH, Jacobsen B, et al. (2013) Biological control editorial board. Elsevier Journal.

5. Naranjo SE, Ellsworth PC, Frisvold GB (2015) Economic value of biological control in integrated pest management of managed plant systems. Annu Rev Entomol 60: 621-645.

6. Marren P, Mabey R (2010) Bugs, Britannica, Chatto and Windus. pp: 122125.

7. (2009) Krantz GW, Walter DE (Eds.), A manual of acarology ( $3^{\text {rd }}$ edn), Texas Tech University Press, Lubbock, Texas, USA, p. 807.

8. Edland T, Evans GO (1998) The genus Typhlodromus (Acari: Mesostigmata) in Norway. European Journal of Entomology 95(2): 275295.
9. Papadoulis GTh, Emmanouel NG, Kapaxidi EV (2009) Phytoseiidae of greece and cyprus (Acari: Mesostigmata). Indira Publishing House, West Bloomfield, Michigan, USA, p. 200.

10. Lenteren JC (2000) A greenhouse without pesticides: Factor fantasy. Crop Protection 19: 375-384.

11. Castagnoli M, Simoni S (1999) Effect of long-term feeding history on functional and numerical response of Neoseiulus californicus (Acari: Phytoseiidae). Exp Appl Acarol 23: 217-234.

12. Griffiths DA (1999) Biological control of mites. In: Albajes R, Gullino ML, van Lenteren JC, Elad Y (Eds.), Integrated pest and disease management in greenhouse crops. Kluwer Academic Publishers, Dordrecht, Netherlands, pp: 217-234.

13. Hart AJ, Bale JS, Tullett AG, Worland MR, Walters KFA (2002) Effects of temperature on the establishment potential of the predatory mite Amblyseius californicus McGregor (Acari: Phytoseiidae) in the UK. J Insect Physiol 48(6): 593- 599.

14. Yeşilayer A, Çobanoğlu S (2015) Tetranychidae (Acari: Prostigmata) species from parks and ornamental plants in Istanbul, Turkey. Gaziosmanpaşa Journal of Scientific Research 11(2015): 90-98. 